\title{
Luis Jerónimo de Oré y la poesía de su Simbolo católico indiano (1598) ${ }^{1}$
}

\author{
Raquel Chang-Rodríguez
}

\section{RESUMEN}

El Concilio de Trento propuso la implementación de nuevos modos de atraer a los neófitos a la fe católica. Siguiendo estas directivas, los concilios eclesiásticos de Lima en el virreinato del Perú, auspiciaron la catequización en lenguas nativas por medio de la publicación de gramáticas y catecismos. Por estar dirigido a los andinos y por sus numerosos himnos en lengua quechua, entre estas publicaciones sobresale Símbolo católico indiano (1598) de Luis Jerónimo de Oré. Este ensayo destaca la importancia

1 Mi gratitud a Nancy Vogeley por su amistad y generosidad al compartir sus ideas sobre los concilios eclesiásticos de Lima y la labor misionera de los franciscanos en el contexto de la política religiosa europea. Gracias a Ramón Mujica Pinilla, director de la Biblioteca Nacional del Perú (2010-2016), por facilitar mis pesquisas en dicha institución. Mi agradecimiento a la Fundación Reed por su constante apoyo a mis investigaciones sobre Oré y su labor misionera en La Florida y Cuba. 
de Símbolo, analiza la temática de los himnos, su relación con antiguas prácticas católicas y cómo los cánticos adquieren un carácter singular en el contexto peruano.

Palabras clave: evangelización, franciscanos, poesía quechua, Luis Jerónimo de Oré, concilios eclesiásticos de Lima

\begin{abstract}
The Council of Trent promoted new ways to attract the neophytes to the Catholic faith. Following these directives, the Lima Church Councils in the Viceroyalty of Peru sponsored the publication of catechisms and grammars in native languages to help missionize the Andean population. Addressed to the indigenous groups and including numerous hymns in Quechua, Simbolo Católico Indiano (1598) by Luis Jerónimo de Oré, is representative of these efforts. This essay underscores the importance of Simbolo; it analyzes the themes of the hymns, their link to ancient Catholic practices, and how they acquire their singularity within the Peruvian context.
\end{abstract}

Keywords: Evangelization, Franciscans, Quechua Poetry, Luis Jerónimo de Oré, Lima Church Councils

El franciscano Luis Jerónimo de Oré (1554-1630) es una de las personalidades más destacadas de la primera generación de intelectuales nacidos en el virreinato del Perú. Oré catequizó a los andinos, viajó a Europa (España e Italia), entrenó sacerdotes para realizar misiones en La Florida, vivió en América del Norte y Cuba, y fue nombrado obispo de Concepción (en el actual Chile) donde murió. Hablante de español, quechua y aimara, escribió varios manuales para cristianizar a los nativos, una biografía de san Francisco Solano (Madrid, ca. 1614), Simbolo católico indiano (Lima, 1598), ${ }^{2}$ Coro-

2 Symbolo Catholico Indiano es el deletreo original, aquí modernizado. El nombre del autor con frecuencia se ha consignado con la antigua ortografía, Luis Gerónimo; aquí sigo la actual. 
na de la Sacratísima Virgen María Madre de Dios Nuestra Señora (Madrid, 1619) y un relato de su estancia en La Florida (¿Madrid, ca. 1619?), un vasto territorio mucho más allá del moderno estado de ese nombre. ${ }^{3}$ Deseoso de contribuir a la catequización de los andinos, Oré compuso numerosos himnos en quechua en alabanza de la Virgen María y sobre diversos aspectos del dogma católico. Los publicó en Simbolo, su obra principal, y constituyen el grupo más numeroso de poesía escrita en ese idioma en el Perú colonial. ${ }^{4}$ La composición de estos cánticos o himnos obedeció tanto a las convicciones del autor como a las nuevas instrucciones para llevar adelante la labor misionera entre grupos de variada procedencia cultural y lingüística.

\section{LA TRANSMISIÓN DEL MENSAJE CATEQUÉTICO}

En el virreinato del Perú, motivados por las directivas del Concilio de Trento (1545-1563), fueron particularmente los concilios eclesiásticos posteriores (1567-1568 y 1582-1584) los que promovieron la enseñanza del quechua y la catequesis en esa lengua. ${ }^{5} \mathrm{Un}$ pasaje frecuentemente citado del Tercer Concilio limeño (15821584) resume el espíritu de estas reglamentaciones: «cada uno ha de ser de tal manera instruido que entienda la doctrina, el Hespañol

3 Para otros detalles sobre su biografía ver Richter (1986), Cook (1992), Tord (1992) y Beyersdorff (2008).

4 La traducción al castellano de Felicita Domínguez, revisada en cuanto a estilo por Julia Beatriz Benavidez, ambas hablantes nativas del quechua y oriundas de Ayacucho, ha facilitado mi lectura y comprensión de este amplio corpus. Se publicó en el estudio de Símbolo de Miguel Ángel Espinoza Soria (2012), que ha circulado mayormente en círculos eclesiásticos peruanos.

5 El jesuita Colegio de San Pablo comenzó a ofrecer instrucción en quechua en 1569. Diez años después, el virrey Francisco de Toledo creó una cátedra dedicada al estudio de esa lengua en la Universidad de San Marcos. Esta funcionó hasta que en 1784 el virrey Agustín de Jáuregui, después de la rebelión de Túpac Amaru en 1780, la eliminó (Porras Barrenechea 1952: ix). 
[sic] en romance, y el indio también en su lengua» (Vargas Ugarte 1951-1954, 1: 325). De este modo, la vulgarem linguam y los idiomas indios se elevaron y equipararon al latín con el propósito de hacer llegar las enseñanzas de la Iglesia a grupos muy diferentes. Como era de esperarse, este respaldo institucional abrió la puerta a la preparación de gramáticas (artes), vocabularios, catecismos, oraciones, cantos, sermones y guías para confesores en lenguas andinas, principalmente el quechua y el aimara. Igualmente, Trento reconoció la importancia de las imágenes para difundir el mensaje evangélico entre los iletrados. Las actas de su $25^{a}$ sesión declararon: «cuando esto sea beneficioso para los analfabetos, deben representarse y mostrarse las historias y narraciones de las Sagradas Escrituras» (en Schroeder 1941: 216). ${ }^{6}$ Esta nueva política de comunicación lingüística y visual, conjuntada con una mayor participación de la población nativa en el culto, cambió la forma de misionar en la región andina. ${ }^{7}$

Como ha señalado Alan Durston (2007), después de estos concilios, la legislación sinodal también propuso una mayor participación de la población nativa en el culto centrada en la liturgia de las horas canónicas. ${ }^{8}$ Igualmente, en esta época la devoción mariana adquirió una importancia única en los pueblos de indios. ${ }^{9}$ Para cumplir con estas nuevas regulaciones, en varias jurisdicciones sinodales como Cusco, los nativos fueron entrenados en el canto de himnos

6 La traducción es mía.

7 Para una revisión de estas políticas en el virreinato peruano, véase Estenssoro Fuchs (2003).

8 En la década de 1580, bajo la dirección del arzobispo Mogrovejo, se estandarizaron varias formas de oraciones: 1) la oración receptiva del Ángelus, recitada todos los días al mediodía; 2) las oraciones por las almas en el purgatorio, recitadas los sábados después de la última oración al final del día (Completas), y 3) la Salve Regina, también recitada después de Completas (Durston 2007: 139-140).

9 Se reforzó en un decreto de 1605 de Pablo V. Este garantizaba indulgencias a quienes «asistieran de rodillas a la salve y las letanías» (Cook 1992: 45). 
y responsorios en misas y festividades (Durston 2007: 139-140). El culto y la instrucción catequética paulatinamente adquirieron un carácter performativo y a la vez contaron con la activa participación de los neófitos indígenas.

\section{Luis Jerónimo de Oré y su Símbolo católico indiano (1598)}

El franciscano huamanguino Luis Jerónimo de Oré fue figura principal en esta tarea misionera. Participó en la preparación de un catecismo trilingüe en español, quechua y aimara, Doctrina cristiana y catecismo para la instrucción de los indios (1584), el primer libro impreso en Lima. Según fuentes franciscanas, trabajó en la redacción del catecismo con otros lenguaraces y un grupo de teólogos, todos especialmente seleccionados para esta tarea. Sin embargo, su nombre no figura en la documentación disponible. Muy probablemente la empresa puso a Oré en contacto con el jesuita José de Acosta, quien había adquirido cierto conocimiento del quechua en sus viajes por el virreinato peruano, y también con Guaman Poma de Ayala, autor de Primer nueva corónica y buen gobierno (1615). No obstante, Rolena Adorno ha advertido que no podemos confirmar la presencia de Guaman Poma en el Tercer Concilio de Lima ni tampoco que haya conocido personalmente a Oré (2000: xlviii).$^{10}$ Sí podemos corroborar que Símbolo católico indiano fue resultado de los argumentos planteados, primero, en Trento y, después, en los concilios limeños. Dirigido a los nuevos cristianos andinos alfabetizados y, en particular, a los indios ladinos cuya labor como intérpretes y traductores en la tarea misionera era admitida pero criticada, el manuscrito circuló en la zona altiplánica antes de publicarse en Lima (Beyersdorff 1993: 219).

10 Sobre la relación entre Oré y Guaman Poma ver también mi ensayo en Libros \& Artes (2016). 


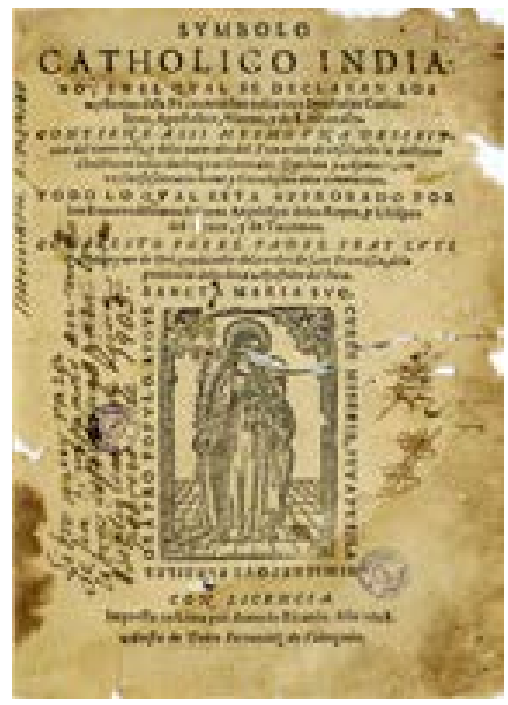

Figura 1.

Portada interior de Símbolo católico indiano, Lima, 1598.

Cortesía de la Biblioteca Nacional, Lima, Perú.

Cuando nos acercamos al libro de Oré, conviene recordar que los credos o símbolos a los cuales nos remite el título (de los Apóstoles, de Nicea y Quicumque) aparecen en un momento de tensión religiosa; además, la formulación de un credo sirve para distinguir a quienes siguen o rechazan una doctrina particular. Los credos de Nicea y Quicumque o Símbolo de Atanasio, por ejemplo, abordan cuestiones doctrinales en disputa. El primero surgió para contrarrestar algunas ideas sobre la divinidad de Jesús (para afirmar que fue engendrado y no creado) y el cuestionamiento del concepto de la Trinidad. El segundo, cuya importancia reconoció Oré al ofrecerlo en latín y traducirlo al quechua en su libro, reafirma la igualdad y divinidad de las tres personas de la Trinidad; sin embargo, a diferencia del Credo de Nicea, agrega condenas o anatemas (castigos) para quienes estén en desacuerdo. Probablemente la influencia más inmediata en el libro de Oré fue el Símbolo de la Fe (Salamanca, 1583) 
del admirado dominico Luis de Granada (1504-1588), escrito en un periodo durante el cual las ideas protestantes amenazaban el catolicismo en la península ibérica. ${ }^{11}$ Símbolo católico indiano también aparece en un periodo crítico, cuando la iglesia en América se encuentra en una época de transición, deseosa de atraer y evangelizar a personas de diversas lenguas y culturas. El adjetivo indiano de su título reafirma la singularidad de su carácter y a quienes se dirige. Cuando aborda el desafío de esta misión evangelizadora, el libro de Oré codifica los preceptos a seguir por quienes acepten la enseñanza católica en Indias. Al hacerlo, reconoce la capacidad de los nuevos cristianos andinos de dominar las herramientas culturales occidentales (incluida la lectoescritura) y de comprender y poner en práctica el dogma. En la sección preliminar del libro, un soneto del padre Jerónimo de Valenzuela, prior del convento de Santo Domingo de Parinacochas, anuncia y confirma el objetivo de Simbolo:

Inculta gente del oculto mundo de niebla oscura hasta aquí cercada, y en el tartáreo piélago anegada del satánico reino furibundo,

despierta ya de sueño tan profundo, y con la luz deífica guiada, al mar tranquilo sal muy confiada de llegar a aquel puerto sin segundo.

Y si saber quisieres el camino deste plácido, ameno, e impíreo puerto, aunque no tengas guía ni piloto,

11 Como explicó el dominico: «Pues contra esta ponzoña, así de herejes [protestantes] como de malos cristianos, servirá como de triaca un pedazo de esta escritura, en la cual declararemos cuán altamente sientan los católicos de este soberano misterio de nuestra Redención [...] engrandezcan este sumo». Dedicatoria, Simbolo, http://www.cervantesvirtual.com/obra-visor-din/introducciondel-simbolo-de-la-fe--0/html/. [Consulta: 29 de agosto de 2015]. 
fray Luys Hierónimo de Oré, ques digno de excelsa loa, te lo muestra abierto en tu lenguaje con su libro docto). ${ }^{12}$

Así, la obra y su autor se constituyen respectivamente en faro y piloto para los cristianos quechuahablantes del Perú. El libro de Oré, según explica el sonetista, les abre el camino al cielo, al «plácido, ameno, e impíreo puerto», a los neófitos andinos. En este tratado encontrarán los principios clave de la fe así como las ideas centrales que informan el pensamiento del franciscano de Huamanga. Vale la pena resaltar algunas.

En Símbolo, Oré relaciona el origen de los indios con la historia bíblica de la caída del hombre de la gracia de Dios y así lo enfatiza en la introducción al quinto cántico: «Nuestro primer principio fue Adán y de Eva, y después, cuando Dios castigó al mundo y perecieron todos los hombres, de solos estos cuatro, de Noé y de sus tres hijos, nos hemos propagado y multiplicado» (Símbolo 1992: 294 [f. 108v]). Oré distingue entre prácticas politeístas y monoteístas y traduce una oración atribuida al Inca Capac Yupanqui asociada con el culto de Pachacamac o el creador supremo, y la cita como evidencia del monoteísmo nativo (Símbolo 1992: 157-158 [ff. 40r-42v]). Identifica al diablo como responsable de los errores en las prácticas católicas nativas (Símbolo 1992: 161-162 [ff. 42r-42v]). Condena a los españoles por su explotación de la población indígena, y específicamente critica la falta de buenos pastores para instruir al nuevo rebaño en la doctrina católica. Si el cristianismo va a florecer, propone, cada pueblo indio debe tener una escuela, un maestro y cantores. Los nativos, argumenta Oré, son totalmente capaces de comprender y asimilar la doctrina cristiana junto con otras herramientas culturales occidentales:

12 Símbolo (1992: 74) [f. 6v]. En las citas de Símbolo empleo la paginación moderna del facsimilar e indico entre corchetes el número de folio. He modernizado la puntuación y el deletreo. 
Que haya escuela y maestro de ella, y cantores diputados y pagados con salario suficiente, donde sean enseñados los muchachos a rezar la doctrina, y a leer y escribir, cantar y tañer. $Y$ de la escuela salgan hábiles en la doctrina, para enseñarla a todo el pueblo. Finalmente, la escuela es como ánima de todo un pueblo para ser mejor doctrinado y regido, y donde no la hubiere, faltará todo lo dicho: de doctrina, música, ornato y servicio de las iglesias, altar y coro. ${ }^{13}$

Al mismo tiempo, como era de esperarse, Simbolo fomenta el culto mariano -hay dos poemas dedicados a la Virgen- y el rezo del rosario. ${ }^{14}$ También pide castigar a quienes no aprendan los principios básicos de la fe. Oré muestra su convicción en la misión franciscana y su capacidad de elevar a los indios a un nuevo nivel en la comprensión del dogma católico; iguala la predicación del Evangelio en el Nuevo Mundo con el trabajo de los Apóstoles llevando las enseñanzas de Jesús a los gentiles (Símbolo 1992: 153 [f. 38r]). Los ministros deben predicar la verdadera doctrina, vivir una vida santa y comportarse con la piedad de un padre hacia los indios; con esta conducta «será idóneo ministro de Cristo y podrá con segura conciencia, si la obediencia le encargare alguna doctrina, tomarla y amarla como esposa» (Símbolo 1992: 165 [f. 44r]). Oré equilibra este ejemplo del buen ministro con la crítica de aquellos más interesados en la ganancia material que en los beneficios espirituales de la predicación.

Símbolo va más allá de un credo. Dirigido a una población nueva y multilingüe capaz de leer y escribir el español, de cantar y comprender el mensaje cristiano, codifica los aspectos esenciales del dogma al tiempo que establece la rutina de los rituales necesarios. Es un credo, pero también una cartilla; es un catecismo, pero también un libro de cánticos o poemas. Sus himnos quechuas y la

13 Simbolo (1992: 189) [f. 56r].

14 Ambos poemas, «Lira a Nuestra Señora del Rosario» (Simbolo 1992: 434 [f. 179v]) y «Alabanza a la Sacratísima Virgen» (Símbolo 1992: 435 [f. 180r]), figuran en quechua. 
manera en que los presenta son una parte integral del nuevo contexto en el cual debe desarrollarse la labor misionera. Si bien Símbolo se puede caracterizar, siguiendo a Raúl Porras Barrenechea, como «la primera prosa científica» escrita en quechua (1952: x), sus cánticos o poemas, a integrarse en la nueva modalidad de culto, ofrecen el más importante conjunto de poesía escrita en ese idioma durante el periodo colonial. En su belleza erudita y compleja imaginería, los versos combinan percepciones culturales de Europa y los Andes y facilitan el acceso al Evangelio. Precaviendo que en su curiosidad y deseo de entender las enseñanzas cristianas, los neófitos querrán ir más allá de los poemas o cánticos, las anotaciones de Oré, a la derecha de los himnos, conducen al Antiguo y Nuevo Testamento, a los escritos de figuras de la Iglesia. De este modo, el franciscano desbroza el trayecto, facilita la navegación hacia el puerto celestial anunciado en el soneto del prior de Parinacochas.

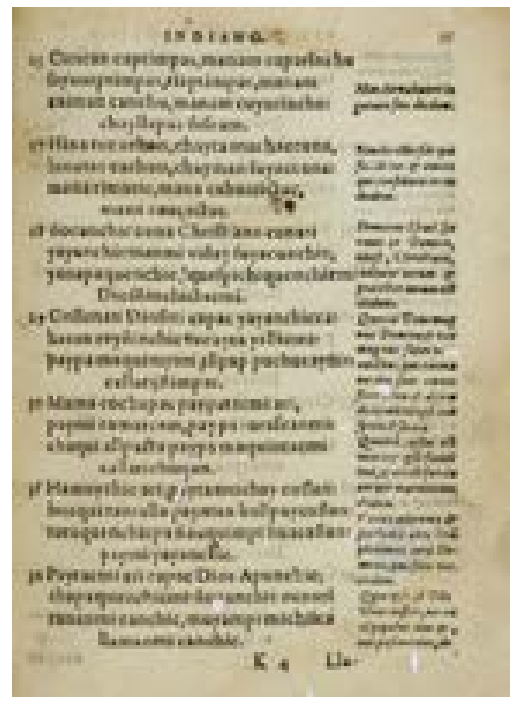

Figura 2. Disposición de los cánticos o poemas; en el margen derecho se incluye la explicación de los principales preceptos, y también citas del Antiguo y Nuevo Testamentos. Símbolo católico indiano, f. 76r. Cortesía de la Biblioteca Nacional, Lima, Perú. 


\section{Los CÁNTICOS}

Oré comienza por recordar la tradición de la Iglesia para explicar la importancia de los cánticos, el tipo de composición y por qué los incluye en Simbolo:

de estos misterios [de la fe] hay compuestos himnos en latín por San Ambrosio y San Gregorio [...] y por otros autores. Y en romance y en toscano, y en las demás lenguas de las naciones que han recibido la cristiandad, hay versos y composturas diferentes en octavas, sonetos y tercetos, canciones y en otros metros de los que encierra la poesía latina, italiana y castellana, lo cual ayuda a alentar la devoción de los documentos y doctrina cristiana $[. .$.$] y nos causa alivio de las continuas molestias de esta$ vida, dar gracias a Dios cantando de corazón salmos y cánticos espirituales como exhorta el apóstol San Pablo a los de Éfeso. ${ }^{15}$

Por lo tanto, siguiendo una práctica aceptada desde los tiempos de los Apóstoles, y como habían hecho después los grandes patriarcas de la Iglesia, Oré, a través de estos himnos, tiene como objetivo ofrecer ayuda y consuelo a los neófitos andinos. Como antes otros feligreses de diversas culturas y lenguas, los andinos deben tener acceso en su propio idioma a adecuadas y variadas herramientas de catequesis y devoción.

El franciscano de Huamanga primero justifica la propuesta de componer sus himnos en metro sáfico, ${ }^{16}$ cuando revisa, comenzando con Horacio, quién lo ha empleado y en qué ocasiones para de este modo prestigiar su selección. Reitera las razones para incluirlos:

15 Simbolo (1992: 202-203) [62v-63r].

16 Explica: «consta de troqueo, espondeo y dáctilo y dos troqueos» (Símbolo 1992: 203-204 [ff. 63r-63v]). El tipo de composición cuyo origen se remonta a Safo, la poeta de Lesbos, se empleó en la Edad Media española en poemas religiosos. Es una estrofa mixta de tres versos endecasílabos sáficos (acentos métricos en la cuarta y octava sílabas) y un cuarto pentasílabo adónico, acentuado en la primera sílaba. Seguramente por las características del quechua, no pudo seguir al pie de la letra el anunciado y prestigioso patrón de rima. 
«[con el canto, los indios], se mueven a devoción, con la letra principalmente, y el tono les sea ayuda y parte para lo mesmo. Cosa muy antigua ha sido en la iglesia imponer a los fieles en semejantes cánticos y alabanzas de nuestro Señor» (Símbolo 1992: 204 [f. 63v]). Oré admite componer los himnos de Símbolo después de mucho estudio y «no sin trabajo grande» (Símbolo 1992: 203 [f. 63r]), con la esperanza de que con la palabra y el ejemplo los indios sean inducidos a alabar a Dios «en los templos y en toda parte, y en las procesiones, dando vuelta en circuito al tabernáculo de Dios, resuene con vociferación en las bocas, almas y corazones de todos el santísimo nombre de Jesucristo» (Símbolo 1992: 205 [f. 64r]). A través de estas composiciones, Oré retoma la dignificación del idioma quechua y sus hablantes. El objetivo parece simple: emplear en los himnos quechuas patrones de rima prestigiosos, remontados a la poesía clásica escrita en griego y latín. Así, los andinos, como los cristianos en otras latitudes y épocas, podrán afirmar su fe a través de la poesía, cantando el mensaje de los Evangelios en su propio idioma y por este medio difundirlo más allá de los muros de la Iglesia. Si bien los cánticos, seguramente por las características del quechua, no siguieron el anunciado patrón de rima, destaca el deseo del autor de prestigiar a cantores y versos, de incorporarlos al cuerpo eclesiástico supérstite.

\section{EstruCtura Y TEMAS}

Como otros misioneros -particularmente los jesuitas-, Oré reconoció la importancia de integrar en el culto cristiano elementos de las culturas indígenas tales como el baile y el canto. ${ }^{17}$ Teniendo esto en cuenta, el autor de Símbolo estipula la hora y la manera en que deben entonarse estos y otros himnos y también cómo deben participar los fieles. Ofrece una verdadera coreografía para cada ocasión litúrgica con el fin de mejorar el aprendizaje del dogma y 
permitir la mayor participación de los neófitos. Así, los siete principales cánticos o poemas están precedidos por un «argumento y una declaración». Cada uno tiene un número variable de versos de diferentes sílabas, trata distintos aspectos del dogma y debe entonarse en un día determinado de la semana. Con el objetivo de abordar las preocupaciones de los hablantes alfabetizados de español y quechua, en el margen derecho el autor indica cuidadosamente las fuentes que respaldan el argumento del poema. A menudo refiere al lector al Antiguo o Nuevo Testamento; igualmente, hay muchas menciones a los salmos, así como a los principales doctores de la Iglesia. En varias ocasiones, Oré hace referencia a la cultura andina y sus patrones de conducta asociándolos cuidadosamente con el dogma cristiano para de este modo facilitar la comprensión de los neófitos. En otras ocasiones, amplía ideas específicas a través del vocabulario o de marcadores léxicos. En cuanto al idioma quechua de los cánticos, Gerald Taylor $(2003: 14,120)$ ha señalado que sigue los lineamientos o modelos lingüísticos propuestos por el Tercer Concilio eclesiástico de Lima en el cual, según fuentes franciscanas, participó Oré. Repasemos ahora al contenido de los poemas.

Precedido por una traducción al quechua del Símbolo de san Atanasio, la primera canción o poema está dedicada a los misterios de la Santísima Trinidad (domingo). En el segundo, el poeta alaba a Dios que habita en el empíreo junto con los ángeles. Él es amado y adorado por sus muchos atributos, así como también por ser el creador del universo (el lunes). El tercer himno alaba al Padre por la creación del hombre y por salvarlo a través del sacrificio de Cristo (el martes). Incluye una rica caracterización de María en su calidad de madre virgen de Cristo. Ella ha derrotado al diablo y se presenta como protectora de la humanidad. Un signo del cielo la ha retratado «vestida del Sol resplandeciente, y la Luna la tenías debajo de tus pies, y tu cabeza una corona de doce estrellas». Se la describe como «aventajada a la luna y a las estrellas», como «tierra bendita y fecunda, monte de Dios, hermoso y grueso, cuajado de flores, azucenas y 
lirios, monte en quien Dios se agradó de habitar para siempre» (Simbolo 1992: 242 [f. 82v]). Siguiendo a san Atanasio, el cuarto himno muestra la encarnación de Jesús como salvador de todos los hombres, así como las virtudes de María (miércoles). La quinta canción trata sobre el origen de la humanidad y responde a las ideas nativas sobre la procedencia de todos los pueblos, subrayando sus raíces comunes (jueves). También enfatiza los Diez Mandamientos y la condena de quienes los transgreden. Concluye con la institución del sacramento de la Eucaristía. El sexto poema se enfoca en la pasión, la muerte y la resurrección de Cristo (viernes). Las crueldades cometidas contra Jesús se presentan a través de imágenes sangrientas asociadas, según Margot Beyersdorff (1993), con la tradición literaria hispánica de describir la Pasión en términos realistas. ${ }^{18} \mathrm{El}$ poema termina con un retrato conmovedor de Cristo crucificado y la idea de la salvación a través de la Sagrada Comunión. El último himno está dedicado a la resurrección de Cristo y la venida del Espíritu Santo (sábado). Explica cómo Jesús es el jefe de la Iglesia y el Papa su vicario en la tierra. Representa las glorias del paraíso obtenidas a través del amor divino, así como los horrores del infierno, reservados para quienes no siguen los mandamientos. El contenido de los cánticos se puede resumir de la siguiente manera:

$1^{\circ}$ : Santísima Trinidad (domingo)

$2^{\circ}$ : Creación del mundo (lunes)

$3^{\circ}$ : Creación del hombre, pecado y redención (martes)

$4^{\circ}$ : Encarnación de Cristo (miércoles)

$5^{\circ}$ : Creación del hombre y la vida de Cristo (jueves)

$6^{\circ}$ : Lamentaciones por la Pasión y la Muerte de Cristo (viernes)

$7^{\circ}$ : Resurrección y glorificación de Cristo. El Espíritu Santo.

El establecimiento de la iglesia (sábado).

18 En este sentido conviene recordar en La Christiada (Sevilla, 1611) del dominico Diego de Hojeda, distinguido miembro de la Academia Antártica, particularmente su descripción del cuerpo herido de Jesús y sus vestimentas ensangrentadas. 
A estos poemas los siguen otros dedicados, por ejemplo, a san Ambrosio y san Agustín, doctores de la Iglesia, y siguen credos, oraciones, mandamientos de la ley de Dios y de la Iglesia ofrecidos en quechua, aimara, español y algunas veces en latín. Como mencioné antes, otros dos -una canción o lira a Nuestra Señora del Rosario y un poema alabando a la Santísima Virgen-, se presentan únicamente en quechua. Concentrándome en los poemas seis y dos, paso a comentar algunas características léxicas y culturales que nos permiten vislumbrar cómo los poemas adquieren su significado entre los neófitos andinos.

\section{Aspectos léXicos y CUlturales}

Por su amplia preparación, Oré estaba consciente de la liturgia católica y de cómo el léxico podía enriquecer o incluso transformar el significado de un poema o verso en particular. Los estudiosos de la lengua quechua han llamado la atención sobre el cambio de código o la meźcla de códigos en su poesía. En este sentido, Alan Durston nota un importante ejemplo de cambio de código en los siguientes versos del poema 6: Lamentaciones para la Pasión y la Muerte de Cristo, el mismo que dice: «cay huañuy caliz Abba Pater Yaya, / yachacuptinca, ñocamanta richun: / huañuy upiayta ama upiashacchu, / munaptiiquica» [«Abba Pater Yaya, si es posible, deja que este cáliz de la muerte se aleje de mí. Si así lo deseas, no beberé la bebida de la muerte»] (2007: 295). ${ }^{19}$ El estudioso señala el uso de la palabra $\mathrm{Pa}$ dre en arameo («Abba»), latín / griego («Pater») y quechua («Yaya»). Haciendo referencia a la sugerencia de Agustín de Hipona de que Cristo usó el vocablo Padre tanto en griego como en arameo en este momento crítico, Durston propone que, al hacerlo, Cristo deseaba

19 Sigo a Durston en esta apreciación de la importancia del cambio de códigos. Reproduzco su versión de este poema; la traducción al castellano es mía. 
establecer la Iglesia, incluyendo a los gentiles y a los judíos. Siguiendo este razonamiento, explica además que, al agregar yaya, Oré proyecta incluir al pueblo quechua en la Iglesia y a la vez conservar los íconos del proceso de traducción que nos remiten a un idioma y una cultura en particular. Este es solo un ejemplo en el que la noción de cambio de código nos ayuda a comprender la manera tan reflexiva como erudita en que Oré les otorgó a los poemas un nuevo giro teológico para incluir a los pueblos andinos en la Iglesia. En su opinión, contaban tanto como los grupos que tradicionalmente se consideraban los pilares de la institución. También muestra, como lo indica Durston, un Cristo inclusivo, invocando al Padre en tres idiomas en coyuntura tan crucial (2007: 293-296).

En el segundo poema de la colección, Creación del mundo, varias estrofas están dedicadas al origen del universo y a alabar la capacidad de Dios para construirlo de la nada. Específicamente, la voz lírica establece un paralelo con la construcción de una casa: amigos y parientes se reúnen, traen el material y construyen muros y techos con mucho esfuerzo:

Runakuna wasikta ruraŝpa, rumiktam ñawpaq maymantapaŝ tawqaq, humpi ŝaykuŝpa apamuŝparaqmi tiqsinta qallap

Ayllu masinwan yanapanakuŝpam pirqanta llamkaq kurkuwanpaŝ chakaq qatanqankama ñakaymantaraqmi puchukakuqpaŝ (Taylor 2003: 130). ${ }^{20}$

20 «Los hombres, cuando construyen sus casas, primero [sacan] las piedras de algún lugar y las juntan; enseguida, con gran esfuerzo, las traen sudando adonde han de poner sus cimientos. Se hacen ayudar por los compañeros de su aillu, levantan los muros, colocan las vigas y finalmente, con duras penas, acaban poniendo el techo». Para el análisis de este poema he usado la versión castellano-quechua de Taylor (2003: 123-147). 
El poema enfatiza cuántas personas se necesitan para construir una vivienda y cuán difícil es realizar este trabajo. Por el contrario, Dios creó el universo y lo ha poblado de la nada, con solo una palabra de su boca. El poema alaba a Dios y lo reconoce como el gran arquitecto del universo. Seguramente en la alusión a la construcción de una casa, los feligreses andinos pudieron reconocer y recordar el ayni o sistema de ayuda mutua, utilizado entonces y ahora para construir casas, caminos y edificios comunales con la cooperación de familiares y amigos del mismo aillu. También conocido como minka o reciprocidad, el ayni es uno de los marcadores singulares de la cultura quechua. De hecho, los miembros de la comunidad ayudan a otros en la agricultura y la construcción de viviendas; cuando los miembros de una familia reciben ayuda para completar una tarea, la única condición es corresponder cuando otros necesiten su colaboración. Ayni y minka tratan sobre el bien común y cómo lograrlo colectivamente. Quienes cantaron, escucharon o leyeron la letra del himno de Oré, familiarizados con el ayni, seguramente apreciaron el esfuerzo colectivo de construir una casa. Como admiraron a quienes participaron en este trabajo común, igualmente pueden maravillarse ante el mayor esfuerzo de Dios, único arquitecto del universo. Propongo que en el poema, Oré usó las imágenes de la construcción del universo y de la casa con sus marcadores culturales, para así darles a entender a los neófitos que ellos eran parte de la creación como pueblo de Dios. De este modo se sentirían comprometidos a corresponder propagando las nuevas del Evangelio y construyendo juntos la nueva iglesia en Perú.

También estos versos incluyen la historia de los ángeles que se unieron a Dios en el «cielo empíreo». El autor los distribuyó en nueve aillus y tres suyus o jerarquías: ángeles y arcángeles están en el primer suyu mientras que virtudes, querubines y serafines están en 
el suyu superior, más cercano al Creador; los otros están en el medio. La mayoría de los ángeles adoraron a Dios; otros, eufóricos con su situación, querían ser como él. La voz lírica aprovecha esta narración para resaltar los problemas del libre albedrío, la transgresión y el castigo. Dios quiere que lo amemos voluntariamente y no por la fuerza, y es por eso que les dio a los ángeles -y a los humanos- la capacidad de elegir entre el bien y el mal. Pero también hay castigo: los ángeles orgullosos, que pensaron ser como Dios, «illapahina rayo qapchahinam / uraykumurqan» [como un relámpago, como un rayo vinieron abajo] (Taylor 2003: 140-141) y fueron directamente al infierno. Otros demonios permanecieron en el aire, escondiéndose en la oscuridad para tentarnos. El poeta menciona los nombres de los arcángeles Miguel y Gabriel, que expulsaron y derrotaron a los ángeles traidores, y Rafael, que sana a los enfermos. Luego volvemos a la narrativa de los orígenes y, a través de referencias elegantes, la voz lírica revisa la creación del cielo, la tierra, los ángeles, el sol, la luna, las estrellas, los arroyos, las colinas, los polluelos, la paloma, los amancaes y los andinos. Incluso las piedras, los minerales y las perlas le deben su belleza al Creador:

Umiñakuna, nina qiŝpi rumi allpap ŝnqunpi quyllurhina situq quchap ukunpi llipyaq perlaskuna sumachiŝqaykim (Taylor 2003: 144-145). ${ }^{21}$

En el poema se alude a las trágicas consecuencias de la transgresión y al amor como un precioso vínculo entre Dios y su crea-

21 «Tú atribuyes su hermosura a las esmeraldas, a los cristales color de fuego que resplandecen como estrellas en las entrañas de la tierra, y a las perlas que brillan dentro del man». (Taylor 2003: 144-145). 
ción (Taylor 2003: 140-141). Este concluye resaltando el poder divino y, por deducción, las ventajas de seguir al todopoderoso Dios cristiano: quienes acepten el Evangelio tendrán su protección y también la de los valerosos arcángeles Miguel, Gabriel y Rafael. Todos deben adorar al Creador porque es superior a las huillcas y las huacas, objetos hechos por hombres de oro, plata, cobre, piedra y madera y, por lo tanto, sin poder para ver y oír. Carecen, agrega el sujeto lírico, del sentido del olfato o del tacto, de la capacidad de caminar y gritar, del «ánima» para moverse. Así, el principio y el fin del universo descansan en las manos de Dios cristiano. Quienes no lo sigan, como los antiguos ídolos, carecerán de palabra, vista o vida (Taylor 2003: 134-135).

En este ensayo he revisado el contexto misionero en el cual se desarrolló Símbolo católico indiano, y por qué Oré utilizó el canto y la poesía para catequizar a la población nativa. Igualmente he comentado el contenido de los cánticos y mostrado su singularidad por medio de un acercamiento léxico y temático a dos de ellos. Para el franciscano de Huamanga, el quechua estaba a la par con el latín y el español como lengua de evangelización. Los pueblos andinos, como otras antiguas colectividades en proceso de cristianización, merecían tener las herramientas adecuadas para afirmar su fe: un libro accesible, un credo inteligible y poemas o cánticos para difundir la devoción y «aliviar los problemas persistentes de esta vida» y también «agradecer a Dios desde nuestro corazón cantando salmos y canciones espirituales». Sin duda, por su número, belleza y sofisticación, la poesía escrita en quechua por este lenguaraz criollo merece estudiarse e incorporarse al acervo lírico peruano. En sus versos percibimos la complejidad del momento histórico en el cual fue pergeñada tanto como el empeño de Luis Jerónimo de Oré por mostrar e igualar la capacidad de europeos y andinos en el virreinato del Perú. 


\section{REFERENCIAS}

Adorno, Rolena

2000 Guaman Poma. Writing and Resistance in Colonial Peru. Austin: University of Texas Press.

Ares QueIJA, Berta

1984 «Las danzas de los indios: un camino para la evangelización en el virreinato del Perú». Revista de Indias, vol. 44, n. 174, pp. 445-463.

BeyERSDORFF, Margot

1993 «Rito y verbo en la poesía de fray Luis Jerónimo de Oré». En: Henrique Urbano (ed.). Mito y simbolismo en los Andes: la figura y la palabra. Cusco: Centro de Estudios Regionales Andinos Bartolomé de las Casas, pp. 215-237.

2008 «Luis Jerónimo de Oré». En: Joanne Pillsbury (ed.). Guide to Documentary Sources for Andean Studies 1530-1900. 3 vols. Norman: University of Oklahoma Press, vol. 3, pp. 472-475.

Chang-Rodríguez, Raquel

2016 «Felipe Huaman Poma de Ayala y Luis Jerónimo de Oré, dos ingenios andinos». Libros \& Artes. Revista de Cultura de la Biblioteca Nacional del Perú, año 13, n. 78-79, pp. 11-14.

Cook, Noble David

1992 «Luis Jerónimo de Oré: una aproximación». En: Symbolo Catholico Indiano. Edición facsimilar de Antonine Tibesar. Lima: Australis, pp. 35-63.

Durston, Alan

2007 Pastoral Quechua. The History of Christian Translation in Colonial Peru, 1550-1650. Notre Dame: University of Notre Dame Press.

Espinoza Soria, Miguel Ángel

2012 La catequesis en fray Luis Jerónimo de Oré OFM. Un aporte a la nueva evangelización. Lima: Provincia Misionera de San Francisco Solano del Perú. 
Estenssoro Fuchs, Juan Carlos

2003 Del paganismo a la santidad. La incorporación de los indios del Perú al catolicismo, 1532-1750. Lima: Instituto Francés de Estudios Andinos; Pontificia Universidad Católica del Perú.

Granada, Fray Luis de 2004 [1583] Introducción del Símbolo de la fe. Alicante: Biblioteca Virtual Miguel de Cervantes. Publicación electrónica. <нtтp://www. CERVANTESVIRTUAL.COM/OBRA-VISOR-DIN/INTRODUCCION-DELSIMBOLO-DE-LA-FE--0/HTML/>. [Consulta: 29 de agosto de 2016].

Oré, Luis Jerónimo

1992 [1598] Symbolo catholico indiano. Edición facsimilar de Antonine Tibesar. Lima: Australis.

Porras Barrenechea, Raúl

1952 «Prólogo». En: Diego González de Holguín. Vocabulario de la lengua general de todo el Perú llamada lengua qq.ichua o del Inca. Lima: Instituto de Historia, Universidad Nacional Mayor de San Marcos, pp. vxliv.

RiCHTER, Federico

1986 «Primera parte: Fray Luis Jerónimo de Oré (biografía) 1554 1630», «Segunda parte: Información de oficio en la Real Audiencia de La Plata del Perú, de los méritos del biografiado (tres piezas)». En: Anales de la Provincia Franciscana de los Doce Apóstoles de Lima. Huamanga: Imprenta de la Universidad de San Cristóbal de Huamanga, pp. 1-41.

TAYLOR, Gerald

2003 El sol, la luna y las estrellas no son Dios... La evangelización en quechua (siglo XVI). Lima: Instituto Francés de Estudios Andinos y Pontificia Universidad Católica del Perú.

TORD, Luis Enrique

1992 «Luis Jerónimo de Oré y el Symbolo Catholico Indiano». En: Symbolo Catholico Indiano. Edición facsimilar de Antonine Tibesar. Lima: Australis, pp. 15-34. 
Trento, Concilio de

1941 Canons and Decrees of the Council of Trent. Traducción e introducción del Rev. H. J. Schroeder, O.P. Rockford, Ill: Tan Books.

VARgas Ugarte, Rubén

1951-1954 Concilios Limenses (1551-1772). 3 vols. Lima: Talleres Gráficos de la Tipografía Peruana. 